\title{
Ginsing Pre-Treatment Lessens The Acute Testis Injury Of Rats Induced By Thioacetamide
}

\author{
Nehal, A.Moustafa \& Amera Tohamey \\ Al-Azhar University,Nasser City. Cairo, Egypt. \\ Zoology Department, Faculity Of Science
}

\begin{abstract}
This work aimed to elucidate the protective action of panax ginseng roots against hazardous effects of thioacetamide $\{\mathrm{TA}\}$ intoxication .Oral administration of thioacetamide $(300 \mathrm{mg} / \mathrm{kg}$ )dissolved in drinking water for 12 weeks greatly affected liver and testis .This appeared from significant increase in serum alkaline phosphatase, serum total acid phosphatase and serum prostate acid phosphatase. Previous starvation for 48 and $72 \mathrm{hrs}$ immediately prior to TA administration strongly potentiated the effects of TA on the serum , testis and liver plasma membrane parameteres. The testis and liver damage may be one of the reasons of the cell death in TA intoxicated rat testis and liver.

However, oral administration of Panax ginseng roots $(117 \mathrm{mg} / \mathrm{kg}$.) for a period of 10 days prior to TA administration performed protective effect against TA toxicity. The obtained results showed that pre-treatment with Panax ginseng roots significantly modulated the changes in the physiological pathway induced by TA intoxication, and that Panax ginseng roots manifested marked improvement in the liver function and the structure of testis and epididymis. Also pre-treatment with ginseng caused a significant reduction in the deteriorated cells and this may support the protection against cellular damaging action.
\end{abstract}

\section{Introduction}

Thioacetamide (TA) is a well known hepatotoxin and hepatocarcinogen (Fitzhugh\&Nelson, 1948).

It's acute administration produced centri-lobular liver necrosis (Hunter et al; 1977).

Environmental agents like TA, chloroform, phalloidin, ECT, are known to cause hepatic injury that may be lead to lethal liver disease such as hepatitis and hepatic failure. High doses of TA inhibit tissue repair and cause hepatic necrosis (Mangipudy et al ; 1995,1996). Studies on the mechanism of development of TA induced injury revealed that TA is metabolized by microsomal cytochrome

p-450 dependent and /or ,non p-450 dependent mixed function oxidases to toxic substances. Low doses of TA stimulate cell division and tissue repair in the liver (Mangipudy, 1995). Ginseng is a plant of medical importance and it has been used by elderly Asians to boost physical and mental vitality (Kiritikar \&Basu, 1987). The biological name of ginseng is Panax quinuefolium_and the Latin name is Panax ginseng._The most important_ part of ginseng is the root. The chemical constituents of this plant root are arabinose, comphor, mucilage, resin, starch and saponin (Food and Drug Administration, 1999). 
The root of ginseng contains more than 18saponins which are considered as the active fractions of ginseng. The majority of which can be classified to 2 groups ,panaxadiol and panaxadiol which trial differ in sugar moiety at the position of carbon 3-6 and 20 (Sanada et al ;1974\&Shogi,1974). The most important energizing ingredients in ginseng are set of compounds called ginsenosides .A second group compounds called panaxanes appeared to reinforce the immune system and help to keep blood sugar levels under control . Panax ginseng is a potent antioxidant and it is effective to reduce tissue damage induced by free radicals (Kitts et al ;2000).

It has been reported that ginseng can reduce chromosomal aberration induced by some chemicals (Umnova et al ;1991), and the saponins in ginseng induce the transcription of cu-zn super oxide dismutase gene which is one of the major antioxidant enzymes(Kim et al ;1996)

Panax ginseng increases immune functions of lymphocytes in elderly (Lin et al ;1995), promotes the phagocytic activity of plaque -mutagenesis forming cells and enhances the mutagenesis of T\&B lymphocytes primed by mitogene ( Yang \&Yu;1999).

Moreover, it has a beneficial effect on the other various hematological parameters (Ferrando et al;1999).Furthermore Panax ginseng prevents myocardial ischemia-reperfusion damage in rats (Maffei-Facino et al ;1999), and it helps to delay experimentally induced heart mitochondrial impairment and muscle contraction deterioration (Toh ,1994).

Additionally., Panax ginseng is free from any harmful side effects (Sanada et al ;1974;Shoji1974\&Aphale et al ;1998). and there is no known drug interactions with Panax ginseng (Food \& Drug Administration , 1999).

Many studies have previously demonstrated that Panax ginseng extr act has a potent antioxidant effect and acts as active free radicals scavenger (Xiaogvang et al ;1998).

In another study, Panax ginseng exerts a stimulatory effect on DNA repair synthesis and has an inhibitory effect on mutagenicity and cellular transformation (Rhee et al ;1990). Moreover it has promoting action on RNA. synthesis in diabetic rats (Yokozawa et al ;1996).

In addition, it was confirmed that Panax ginseng has a therapeutic properties which can enhance immune function (Yun et al ;1996 \& Shin et al ;2000).

The purpose of this study was to evaluate the potential protective action of Panax ginseng root against thioacetamide toxicity particularly on liver function and the structure of testis and epididymis of adult male rats .

\section{Materials And Methods}

64 male albino rats weighting 250$275 \mathrm{~g}$ were included in this study, rats were divided into 8 groups each group contained 8 rats and served as follows :-

- Group 1 : control .

- Group 2: treated with Panax ginseng $(117 \mathrm{mg} / \mathrm{kg})$.

- Group 3: treated with300 mg $/ \mathrm{kg}$ TA and dissected after $24 \mathrm{~h}$ (TA24).

- Group 4: treated with300 mg /kg TA and Panax ginseng and dissected after24h (G+TA24).

- Group 5: treated with300 mg $/ \mathrm{kg}$ TA and dissected after $48 \mathrm{~h}$ (TA48).

- Group 6: treated with300 mg $/ \mathrm{kg}$ TA and Panax ginseng and dissected after48h (G+TA48). 
- Group 7: treated with300 mg /kg TA and dissected after.72h (TA72).

- Group 8: treated with $300 \mathrm{mg} / \mathrm{kg}$ TA and Panax ginseng and dissected after72 h (G+TA72).

The dose of TA was $300 \mathrm{mg} / \mathrm{kg}$, dissolved in drinking water for 12 weeks . Rats were studied 2 days after the end of TA treatment . Ultra pure chemicals were used in this study and obtained from Sigma chemicals co.

The dose of Panax ginseng was 117 $\mathrm{mg} / \mathrm{kg}$, it was used freshly suspended in distilled water and it was given by stomach tube .Powder of Panax ginseng root (aqueous extract).was obtained from IPECO company 10 th of Ramadan city , Egypt .

For physiological measurements, blood was collected by scarifying thro ugh jugular vein in a clean dry centr ifuge tubes, kept for $30 \mathrm{~min}$. at $37 \mathrm{c}^{\circ}$ and centrifuged at $3000 \mathrm{rpm}$ for $15 \mathrm{~min}$ The sera were collected in a clean Epindorf tubes and kept at $20 \mathrm{c}^{\circ}$ until analysis.

\section{Tissue sampling :}

Liver and testes were removed and their weights were recorded, then homogenated in dist. water .

The alkaline phosphatase (Alp) was measured according to Kochmar and Moss (1976), total acid phosphatase (Acp) was measured according to Moss(1984). The glutathione (GSH) was detected using DTNB chromogen according to Beutler (1963).

\section{Statistical analysis :-}

Data were expressed as means \pm standard errors. The $\mathrm{T}$ test was used to elucidate the differences between treated and control groups . (Snedecor ,1967). The difference was considered significant at $\mathrm{p}<0.05$.
For histopathological studies testes were surgically removed from rats then fixed in neutral

buffer formol, paraffin sections (5 $\mu$ ) were stained with haematoxylin and eosin (Durury and Wallington (1980) .

For histochemical studies, PAS + ve materials were demonstrated using the periodic Acid Schiff technique (Trayer ,1980)

\section{Results}

Data in table (1) , indicate a statistically significant increase in serum alkaline phosphatase (Alp), in different treated groups when compared to control group and ginseng group. Treatment with ginseng and TA at $48 \mathrm{~h}$ (G+TA 48 ), exhibited a slight decrease in serum Alp. Total Acp level decreased significantly in $\mathrm{G}$ group , TA $24, \mathrm{G}+$ TA 24 ,\&TA48 groups when Compared to control. However the level of Acp increased significantly in G+TA 48 , TA $72 \&$ G+TA72 groups in comparison with control. On the other hand, serum prostatic acid phosphatase was reduced showing a significant difference between G, TA24 ,G+TA24 and control groups . However, a high significant increase occurred in the level of serum prostatic in TA $48, \mathrm{G}+\mathrm{TA} 48$ \& TA 72 groups when compared with control one.

Data presented in table( 2 ), showed that the TA 24, TA48 \& G+TA48 treated groups were significantly decreased in testes Glutathione (GSH) and in group G+TA24 \&TA72 there was a significant increase when compared with control .

However in groups G\&G+TA 72 , no change was observed. On the other hand high level of testes Alp in different treated groups was observed in 
comparison with control, but G+TA48 group showed a significant decrease .

Testes acid phosphatase (Acp) content was decreased significantly in G,G+TA48,TA72 \&G+TA24 treated groups compared with control .

Histopathological results of the testis and the epididymis :-

The normal histological structure of the testis and the epididymis was observed in fig.(a,b). Epididymis consists of inner layer of pseudo stratified ciliated columnar cells with non motile cilia, this layer rests on the outer basement membrane .

The treatment of rats with ginseng showed an increase in the spermatog enesis activity in testis with increased density of spermatozoa in the epididymis ffig. $2 \mathrm{a} \& \mathrm{~b}\}$.

The third group of rats treated with TA24, showed disturbed and reduced spermatogenesis . Debris of Leydig cells and spermatozoa could be detected, most of them appeared devoid of their nuclei. Moderately affected epididymal tubules Contained less number of spermatozoa.

Group of rats treated with ginseng and TA24 (fig.4a\&b ), showed partially improvement in the spermatogenic activity in the testis and the density of spermatozoa in the epididymis. .Group of rats treated with TA48 fig .5 a\&b \}, showed disturbed spermatogenesis in most seminiferous tubules . Ruptured Pyknotic and enlarged nuclei could be observed .Also signs of karyolysis could be detected . Disturbed and enlarged walls of epididymal tubules contained a few number of sperms . Inter tubular fibrous tissue could be observed inbetween these tubules .

In rats treated with ginseng and TA48, signs of improvement could be observed while some primary sperma tocytes contained enlarged nuclei with The normal appearance of epididymis $\{$ fig .6a \& b $\}$.

Disturbed spermatogenic activity which was accompanied by reduction in the number of spermatogenic cells could be noticed in rats treated with TA72 . Nearly all seminiferous tubules appeared devoid of sperms with sparing of their tails. Empty and reduced epididymal tubules could be noticed with increased inter tubular fibrous tissue $\{$ fig. $7 \mathrm{a} \& \mathrm{~b}\}$.

Signs of recovery could be observed in rats treated with ginseng and TA 72in testis and the epididymis .Debris of some spermatogenic layers could be noticed with vacuolated Leydig cells. Few sperms were observed in epididymal tubules fig. $8 \mathrm{a} \& \mathrm{~b}$ \}.

Normal distribution of PAS+ve material was noticed in fig . $9\{a \& b\}$. Moderate reaction in spermatogenic layers with dense reaction in Leydig cells and basement membrane were observed . Columnar cells of epididymis and head of spermatozoa showed dense reaction, with moderate reaction in the remnant layers .

In group of rats treated with ginseng a slight increase in PAS + ve material was observed in the testis, while dense reaction was noticed in spermatozoa and different types of epididymal cells $\{$ fig. $10 \mathrm{a} \& \mathrm{~b}\}$.

In group of rats treated with TA 24 , PAS+ve reaction was moderate in Leydig cells and basement membrane and weak in spermatozoa. Moderate reaction was noticed in spermatozoa inside the epididymal tubules and the border of columnar cells, with weak reaction in few epididymal tubules ffig. $11 \mathrm{a} \& \mathrm{~b}\}$.

Group of rats treated with ginseng and TA24, showed a slight increase 
PAS+ve material especially in spermatozoa layer with less reaction in the epididymis $\{$ fig $.12, a \& b\}$.

Rats treated with TA48, showed a decrease in PAS+ve reaction in testis and the epididymis with moderate to weak reaction in inter -tubular fibrous tissue \{fig .13a\&b\}.

Group of rats treated with ginseng and TA48, showed a slight increase in PAS+ve reaction especially in spermatozoa layer with moderate reaction in the epididymis \{fig .14 a\&b\}.In group of rats treated with TA72, very weak PAS+ve reaction was noticed in the testis and the empty epididymal tubules \{fig. $15 \mathrm{a} \& \mathrm{~b}\}$. While slight signs of improvement could be observed in rats treated with ginseng and TA72 as a result of appearance of spermatozoa. Thick fibrous tissue inbetween epididymal tubules moderately stained . Disturbed and reduced columnar cells appeared less stained ffig .16a\&b\}

Table (1) : Serum alkaline phosphatase (ALP), total acid Phosphatase (T.CAP) and prostatic acid phosphatase in different treated groups.

\begin{tabular}{|c|c|c|c|c|c|c|c|c|}
\hline & $\mathrm{C}$ & G & TA 24h & $\begin{array}{c}G+T A \\
24 h\end{array}$ & TA 48h & $\begin{array}{c}\mathrm{G}+\mathrm{TA} \\
48\end{array}$ & TA $72 \mathrm{~h}$ & $\begin{array}{c}\mathrm{G}+\mathrm{TA} \\
72\end{array}$ \\
\hline Serum & & & * & $*$ & $*$ & $*$ & * & $*$ \\
\hline Alp & 49.00 & 48.33 & 61.39 & 62.72 & 51.89 & 43.01 & 55.56 & 51.90 \\
\hline $\mathrm{U} / \mathrm{L}$ & +3.10 & +3.56 & +5.57 & +2.99 & +5.23 & +2.5 & +3.94 & \pm 4.87 \\
\hline Serum Total & & & $*$ & $*$ & $*$ & $*$ & $*$ & $*$ \\
\hline $\mathrm{ACP}$ & 11.11 & 11.01 & 8.75 & 10.30 & 10.44 & 12.64 & 14.54 & 13.63 \\
\hline $\mathrm{U} / \mathrm{L}$ & \pm 2.02 & \pm 1.26 & \pm 0.41 & \pm 1.79 & \pm 1.35 & \pm 1.17 & \pm 1.70 & \pm 0.93 \\
\hline Serum Prostatic & & $*$ & $*$ & $*$ & $*$ & $*$ & $*$ & $*$ \\
\hline $\mathrm{ACP}$ & 7.07 & 6.06 & 5.72 & 6.73 & 7.58 & 8.08 & 8.59 & 8.58 \\
\hline $\mathrm{U} / \mathrm{L}$ & +0.9 & +5.58 & \pm 0.5 & \pm 1.16 & \pm 1.1 & \pm 0.71 & \pm 0.43 & \pm 0.43 \\
\hline
\end{tabular}

All values represent $\mathrm{M} \pm \mathrm{S}$.E. of 5 animals.

* Significant at $\mathrm{P}<0.05$.

Table (2) : Testis, glutathion (GSH), alkaline phosphatase (ALP) and testis acid phosphatase (ACP) in different treated groups.

\begin{tabular}{|c|c|c|c|c|c|c|c|c|}
\hline & $\mathrm{C}$ & $\mathrm{G}$ & $\mathrm{TA}$ & $\mathrm{G}+\mathrm{TA}$ & $\mathrm{TA}$ & $\mathrm{G}+\mathrm{TA}$ & $\mathrm{TA}$ & G+TA \\
& & & $24 \mathrm{~h}$ & $24 \mathrm{~h}$ & $48 \mathrm{~h}$ & $48 \mathrm{~h}$ & $72 \mathrm{~h}$ & 72 \\
\hline Testis & & & $*$ & $*$ & $*$ & $*$ & $*$ & \\
GSH & 10.49 & 10.06 & 5.52 & 11.35 & 5.33 & 5.46 & 8.59 & 10.04 \\
mg/g Wet.tissue & \pm 1.11 & \pm 1.65 & \pm 0.43 & \pm 0.06 & \pm 0.52 & \pm 0.78 & \pm 1.63 & \pm 1.39 \\
\hline Testis & & $*$ & $*$ & $*$ & $*$ & $*$ & $*$ & $*$ \\
Alp & 310 & 312.61 & 361.61 & 352.6 & 338.0 & 288.85 & 431.67 & 420.33 \\
U/g fresh wet. & \pm 35.41 & \pm 53.36 & \pm 42.43 & \pm 47.50 & \pm 53.43 & \pm 22.63 & \pm 49.71 & \pm 74.41 \\
Tissue & & & & & & & & \\
\hline Testis & & $*$ & $*$ & $*$ & $*$ & $*$ & $*$ & $*$ \\
ACP(U/g) & 65.95 & 61.70 & 75.03 & 70.74 & 74.35 & 64.56 & 60.73 & 59.77 \\
Fresh wet. tissue & \pm 4.65 & \pm 9.98 & \pm 1.73 & \pm 3.06 & \pm 3.51 & \pm 3.60 & \pm 2.42 & \pm 4.47 \\
\hline
\end{tabular}

All values represent $\mathrm{M} \pm \mathrm{S}$.E. of 5 animals.

* Significant at $\mathrm{P}<0.05$. 


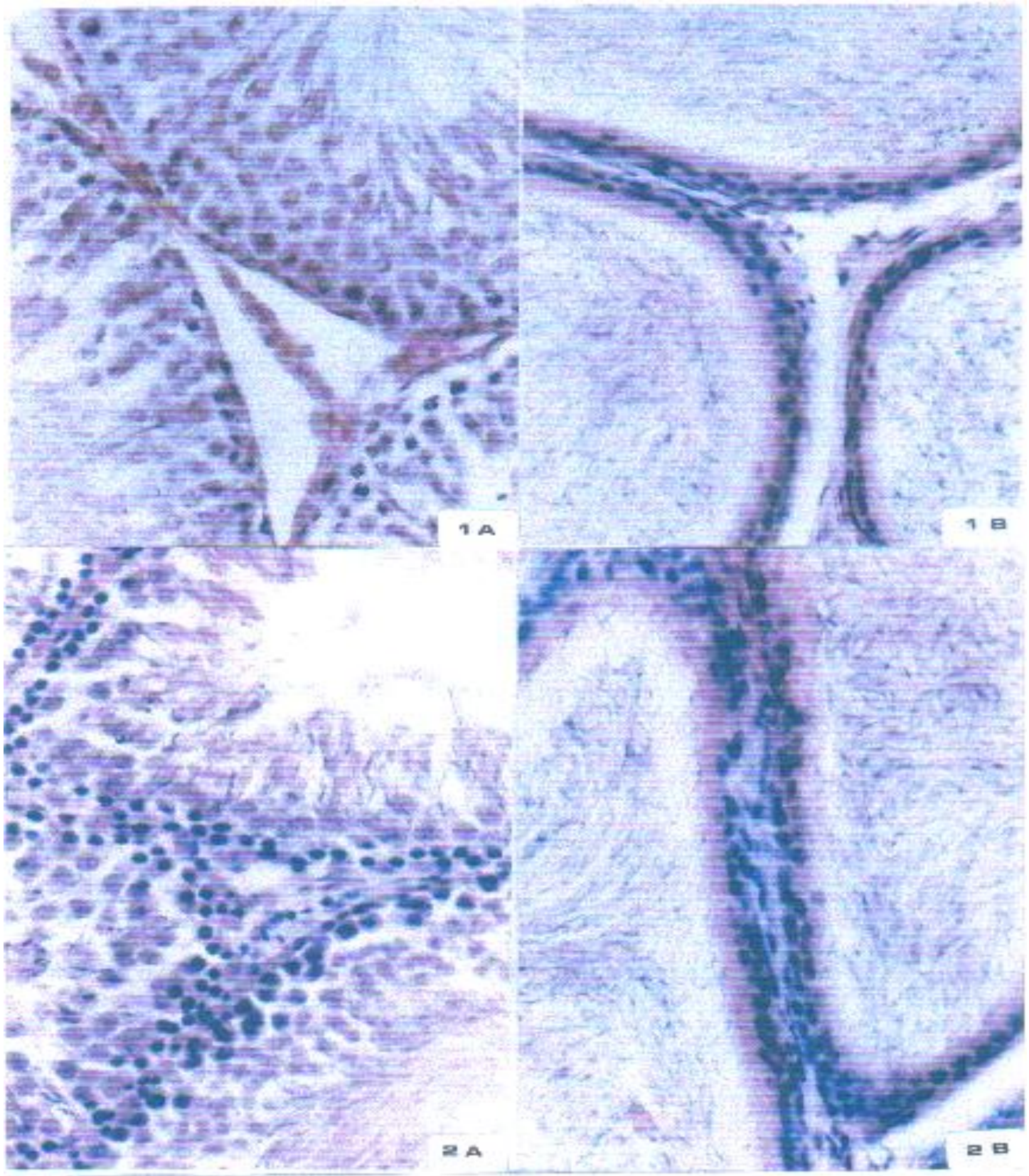

Fig. 1 ( a , b ) sections in control testis ( a ) and epididymis ( b ) of a rat, showing typical arrangement of germ cells in the testis. The epididymis consists of epididymal tubules, each of them consists of pseudostratified columnar ciliated cells and the basement membrane layer

( Hx \& E x 400 )

Fig. 2 ( a , b) section in testis and epididymis of rats treated with ginseng, showing an increase in the spermatogenic activity ( a ) . notice the increase in the density of spermatozoa in the middle of epididymis ( $b$ )

( Hx \& E x 400 ) 


\section{Ginsing Pre-Treatment Lessens.......}

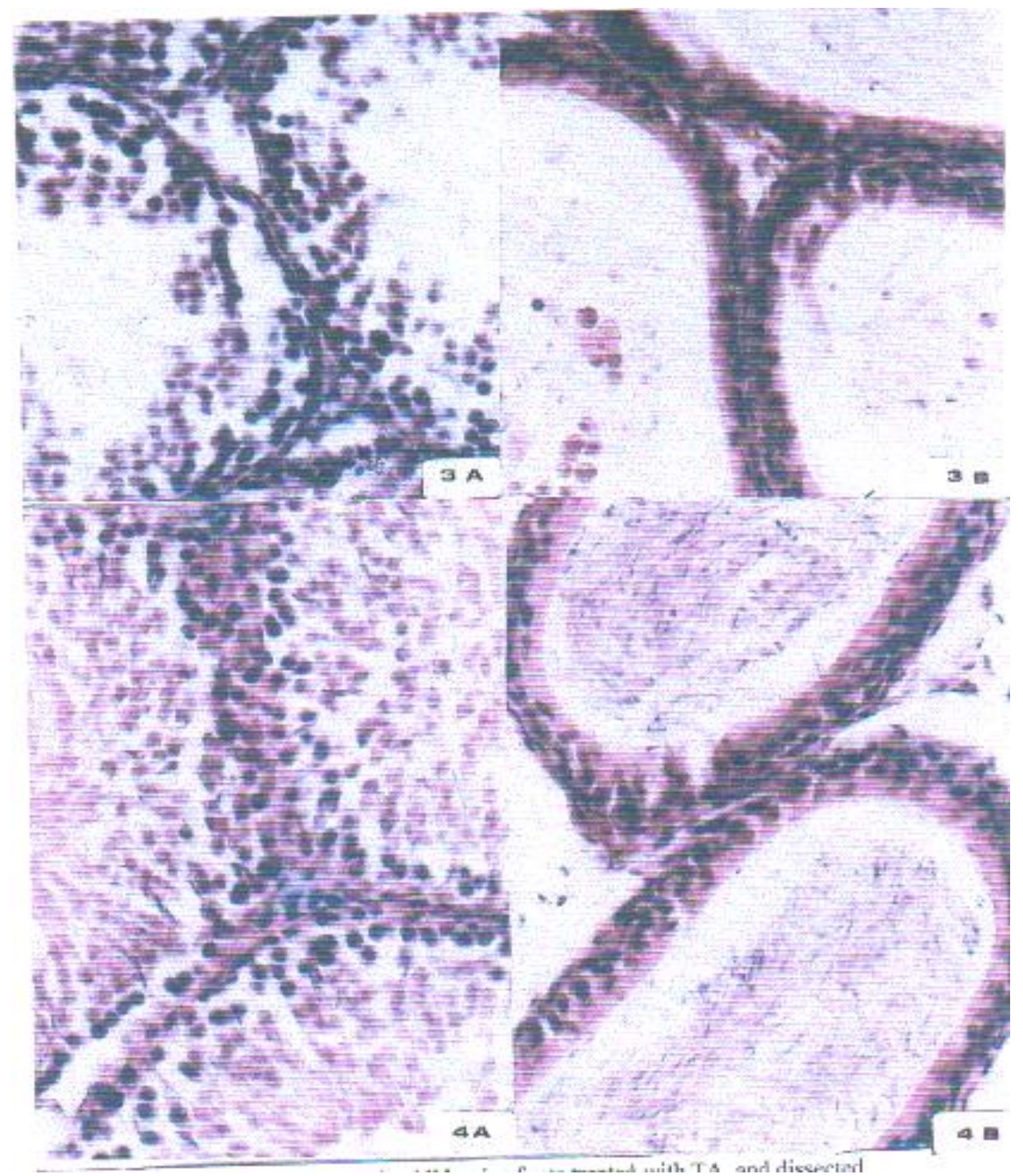

Fig. 3 ( a , b ) sections in testis and epididymis of rats treated with TA and dissected 24 hours post-treatment, showing disturbed and reduced spermatogenesis in some seminiferous tubules, the remnant tubules contained highly affected spermatozoa which appeared devoid of their nuclei . Leydig cells also appeard influenced ( a) The epididymal tubules were highly affected with detached cilia ( $b$ ), they also contained reduced number of spermatozoa $(\mathrm{c})$

(Hx \& E x 400$)$

Fig. 4 ( $\mathbf{a}, \mathbf{b}$ ) sections in testis and epidiymis of rats treated with TA and ginseng and dissected 24 hours post-treatment, showing partial improvement in the spermatogenic activity ( a ) \& the density of spermatozoa in the epididymis ( b )

( Hx \& E x400) 


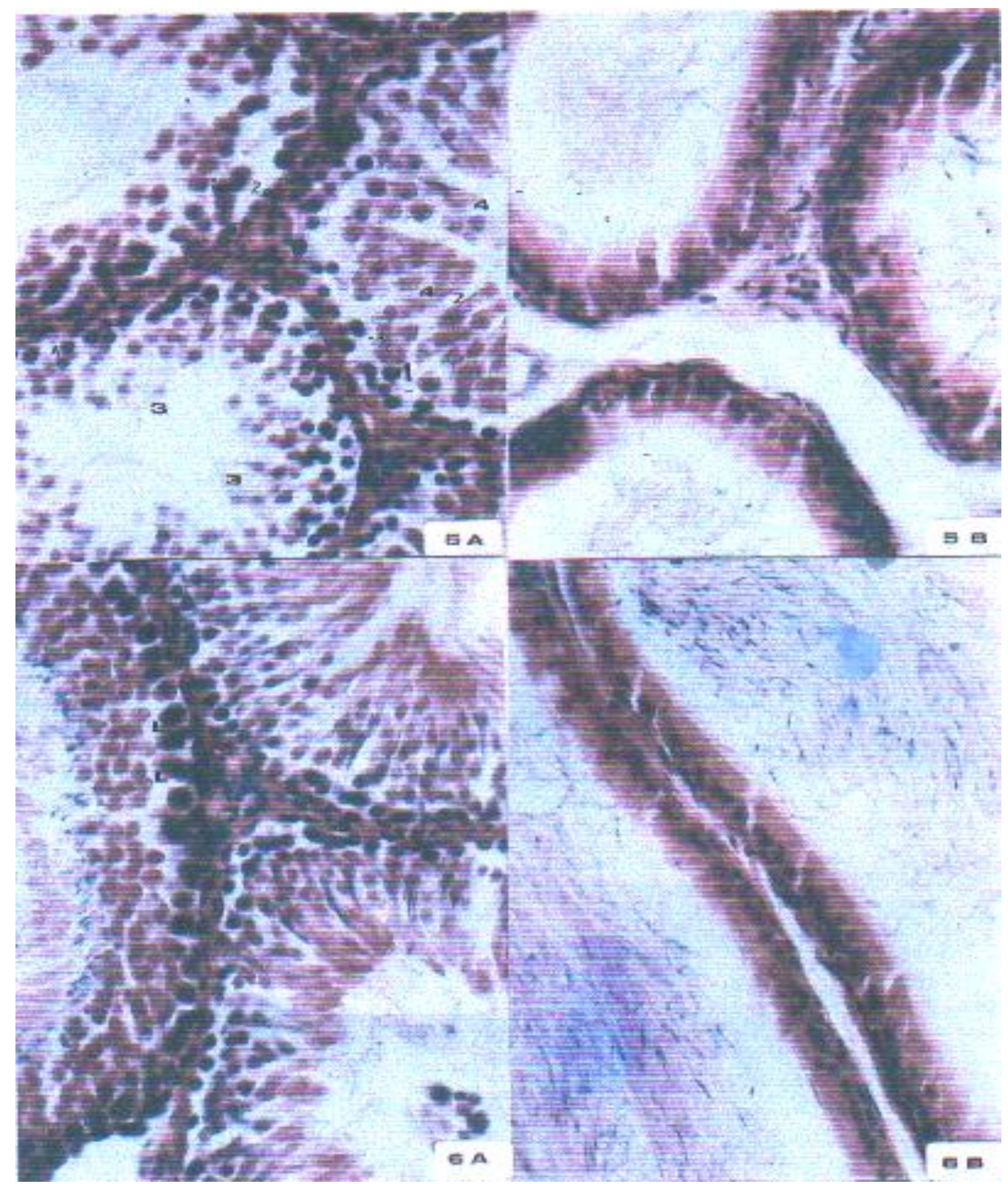

Fig. 5 ( $\mathbf{a}$, b ) sections in testis and epididymis of rats treated with TA and dissected 48 hours, showing disturbed spermatogenesis in most seminiferous tubules, some nuclei appeared pyknotic ( 1 ), enlarged ( 2 ), ruptured ( 3 ). Signs of karyolysis (4) could be detected, some seminiferous tubules appeared devoid of spermatozoa ( a ). Notice enlarged and disturbed epididymal wall, iner-tubular fibrous tissue could be observed (b )

( Hx \& E x400)

Fig. 6 ( a , b ) sections of testis and epididymis of rats treated with TA and ginseng and dissected after 48 hours, showing signs of improvement, while some primary spermatocytes contained enlarged nuclei and cytoplasm with the normal appearance of most spermatogenic layers ( a ). Notice the normal appearance of spermatozoa in the epididymis ( b )

( Hx \& E x400) 


\section{Ginsing Pre-Treatment Lessens.......}

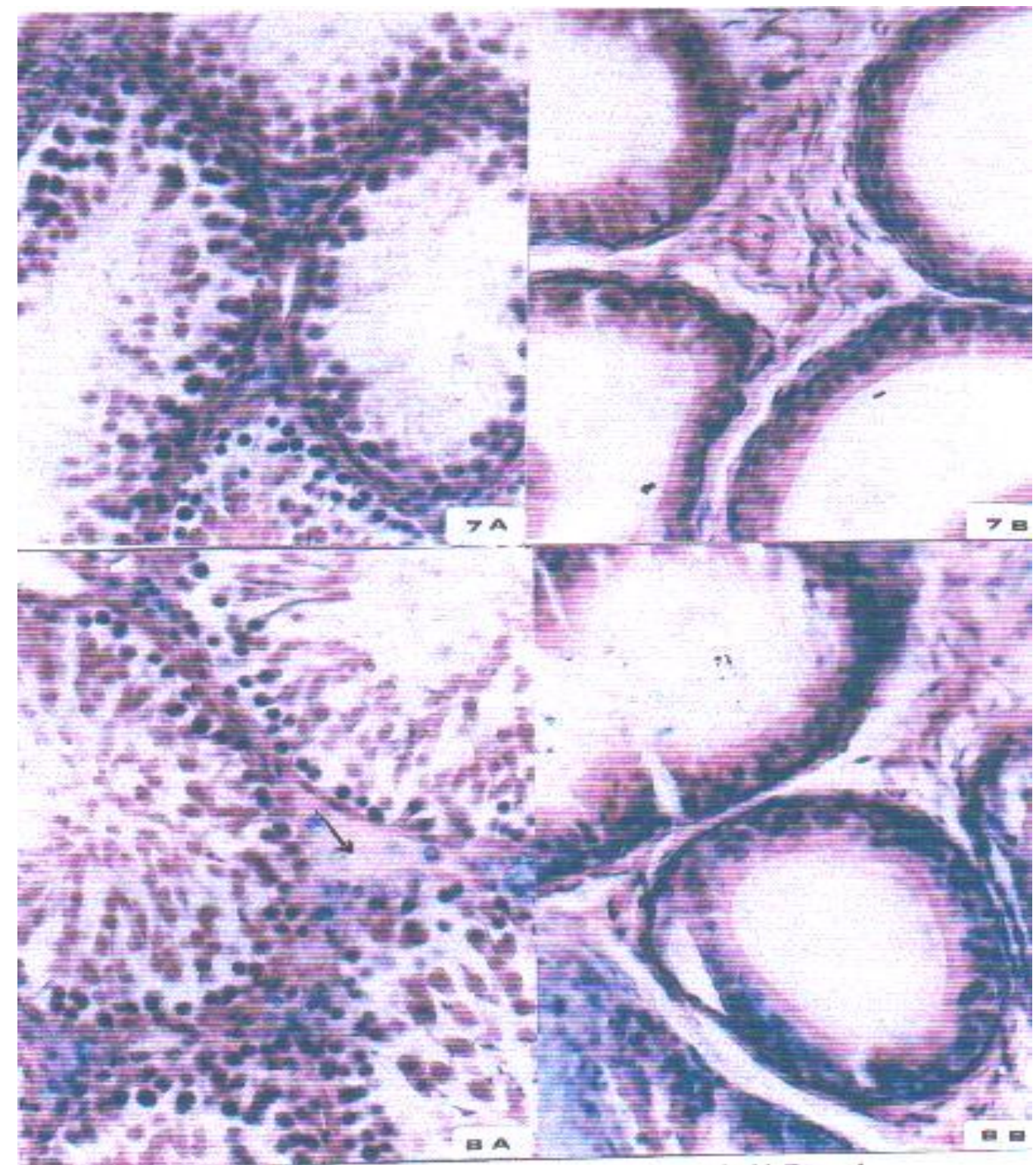

Fig. 7 ( $\mathbf{a}, \mathbf{b}$ ) section in testis ( a ) and epididymis ( b ) of rats treated with TA and dissected 72 hours post-treatment, showing disturbed spermatogenic activity accompanied by reduction of the number of spermatogenic cells , nearly all seminiferous tubules appeared devoid of spermatozoa with spairing of their tails .The epididymal tubules appeared reduced and contain no spermatozoa with an increase in the inter-tubular fibrous tissue

( Hx \& E x400)

Fig. 8 ( $\mathbf{a}, \mathbf{b}$ ) sections of testis and epididymis of rats treated with TA and ginseng and dissected 72 hours post-treatment . Notine signs of recovery in the testis (a) and epididymal tubules ( $\mathrm{b}$ ), debris of some spermatogenic cells could be detected and also inter-tubular vaculation, few spermatozoa could be noticed in the epididymal tubules

( Hx \& E x 400 ) 


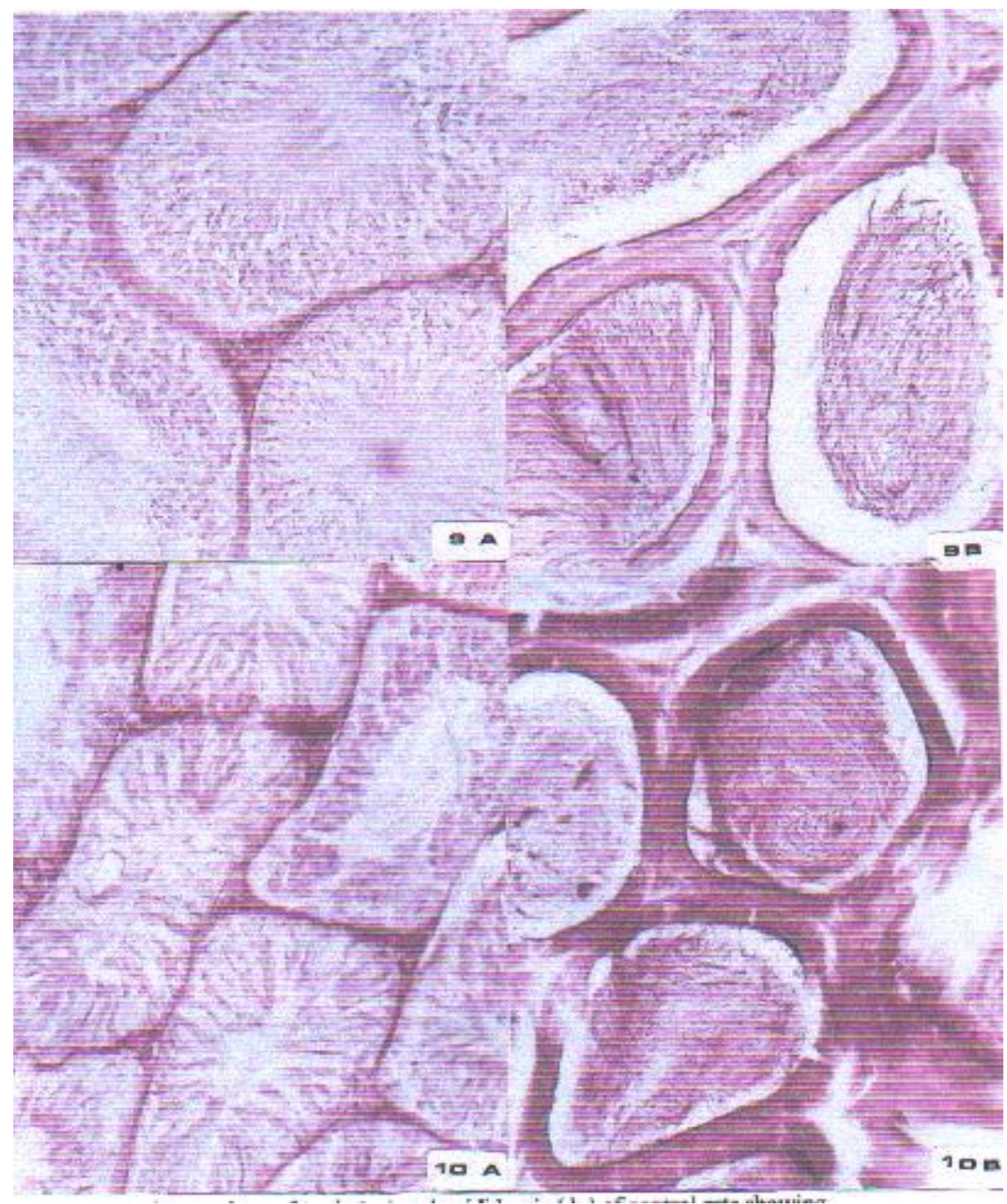

Fig. 9 ( a , b ) sections of testis ( a ) and epididymis ( b ) of control rats showing moderate $+v e$ PAS reaction in the spermatogenic layers, and dense reaction in the Leydig cells and basement membrane of seminiferous tubules. In the epididymis; dense reaction in the border of the columnar cells and the head of the spermatozoa, moderate reaction in the remnant layers could be observed .

(PAS x 200)

Fig. 10 ( a , b ) sections of testis ( a ) and epdidymis ( b ) of rats treated with ginseng showing a slight increase in +ve PAS reaction in the testis while dense reaction could be detected in the spermatozoa and different types of cells of the epididymal tubules

( PAS x 200) 


\section{Ginsing Pre-Treatment Lessens.......}

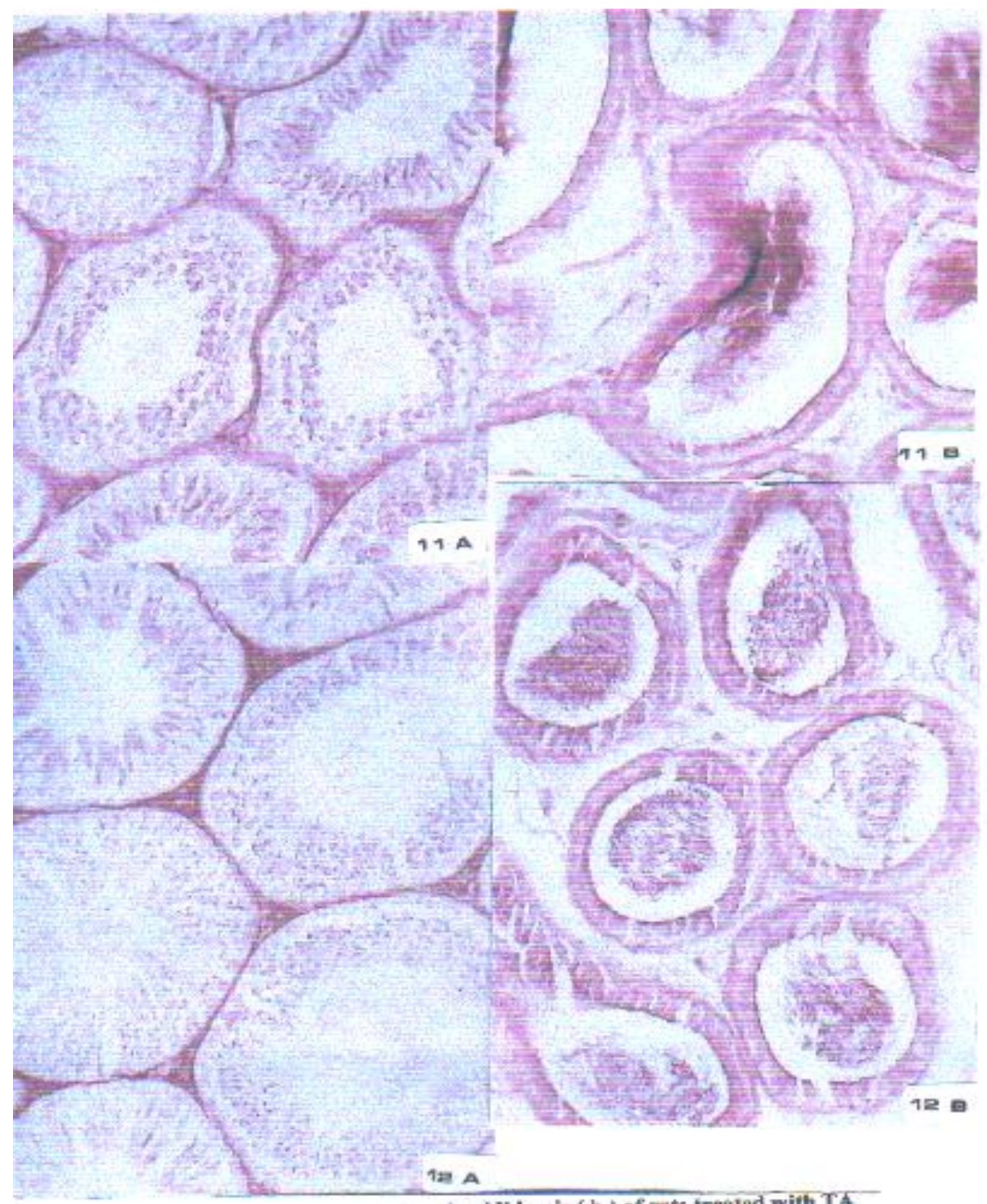

Fig. 11 ( $\mathbf{a}, \mathbf{b}$ ) sections in testis ( a ) and epididymis ( b ) of rats treated with TA and dissected after 24 hours, notice that +ve PAS reaction was moderate in Leydig and basement membrane, weak reaction in the spermatozoa, moderate reaction in the spermatozoa inside the epididymal tubules and the border of the columnar cells . Less activity could be observed in the other layers, while weak reaction could be observed in few epididymal tubules

( PAS x 200 )

Fig. 12 ( a , b ) section in the testis ( a ) and epididymis ( b ) of rats treated with TA and ginseng and dissected after 24 hours showing slight increase in the +ve PAS reaction especially in the spermatozoa layer in the testis .Less reaction could be observed when compared with the control epididymal tubules

( PAS x 200 ) 


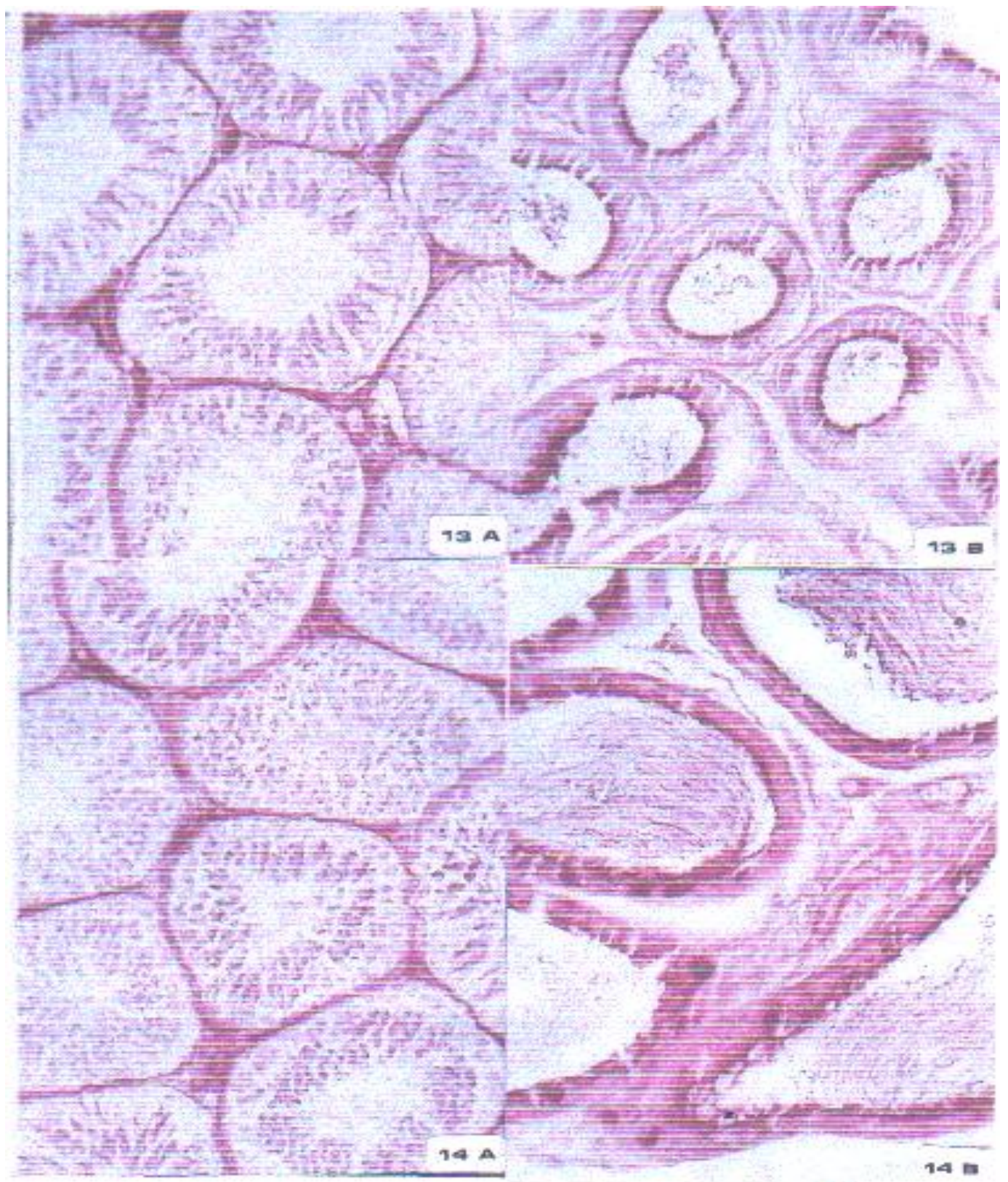

Fig. 13 ( a , b ) section in the testis ( a ) and epididymis ( b ) of rats treated with TA and dissected after 48 hours showing decreased reaction in the testis and epididymal tubules especially in the spermatozoa . Notice the reduction of epididymal tubules which is accompanied with moderate to weak reaction in the inter-tubular fibrous tissue

( PAS x 200)

Fig. 14 ( a , b ) sections in testis ( a ) and epididymis ( b ) of rats treated with TA and ginseng and dissected 48 hours showing a slight increase in the +ve PAS reaction in the testis especially I the spermatozoa layer in some seminiferous tubules, while moderate increase in the reaction was noticed in the spididymis.

$(\mathrm{PAS} \times 200)$ 


\section{Ginsing Pre-Treatment Lessens.......}

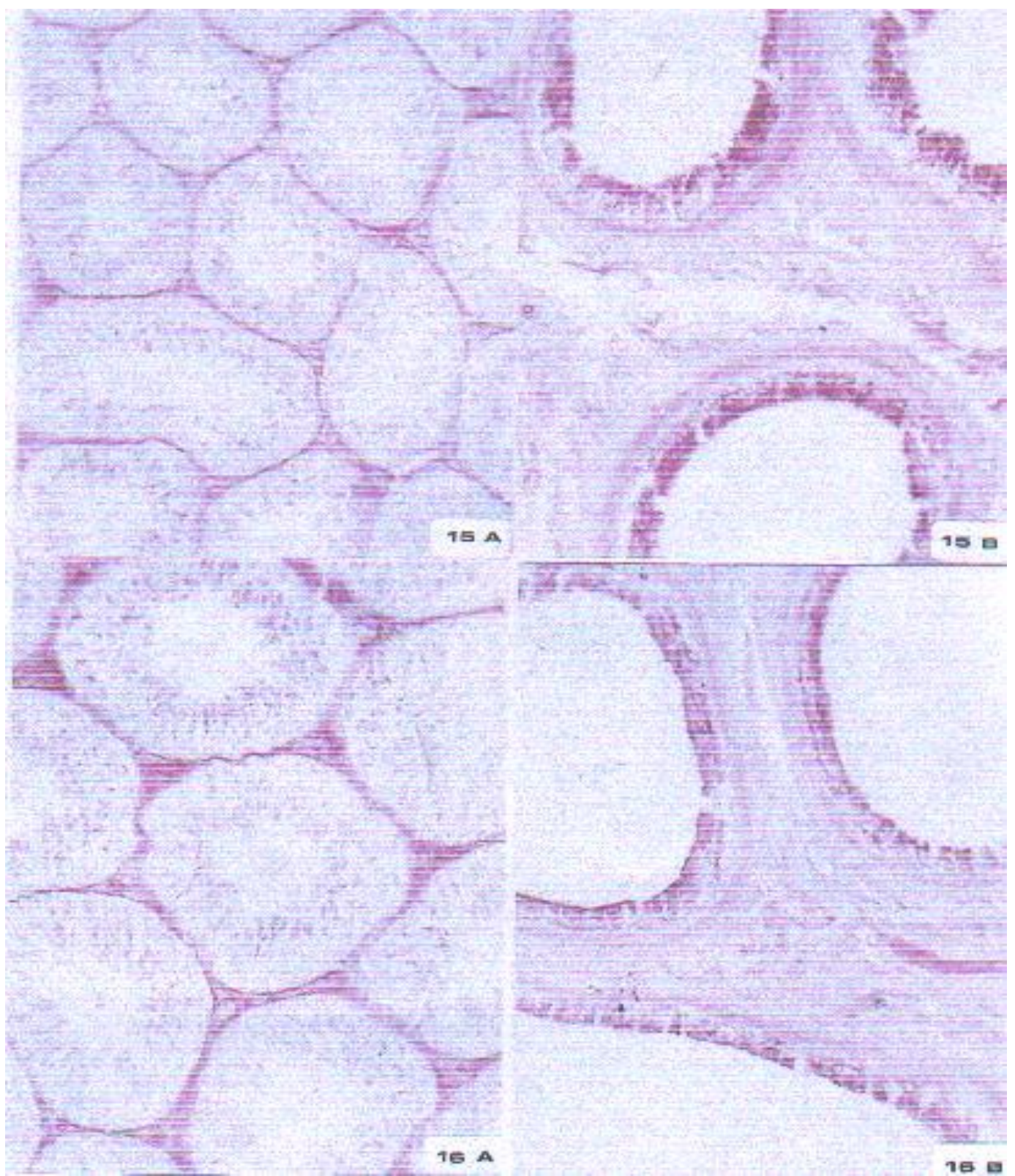

Fig. 15 ( a , b ) section in testis ( a ) and epididymis ( b ) of rats treated with TA and dissected after 72 hours showing very weak reaction inside seminiferous tubules and in the fibrous tissue inbetween epididymal tubules. Seminiferous and epididymal tubules appeared devoid of spermatozoa accompanied with a -ve reaction

( PAS x 200 )

Fig. 16 ( a , b ) section in the testis ( a ) and epididymis ( b ) of rats treated with TA and ginseng and dissected 72 hours post-treatment showing slight sighs of improvement in the middle of seminiferous tubules which was accompanied with appearance of few spermatozoa in the testis. Thick fibrous tissue inbetween epididymal tubule appeared moderately stained while disturbed \& reduced columnar cells appeared less stained

(PAS x 200$)$ 


\section{Disussion}

Many chemical and physical agents cause damage in different tissues of the body, one of these agents is thioace tamide. The formation of free radicals and cytotoxic oxygen metabolites probably play a key role in various types of tissue degeneration such as cancer and retinal degeneration (Brown , 1995). In order to overcome the effect of free radicals and to reduce the damaging effect of oxidants, a variety of pharmacological antioxidants such as glutathione has been examined (Gutteridge, 1986). This study is an attempt to investigate the effect of Panax ginseng root in modulating the toxic effect induced by TA administration in adult male rats Thioacetamide is well known as hepatotoxin and hepatoca rcinogen agent (Hunter et al ;1997 ) .TA treatment resulted in striking loss of specific liver plasma membrane enzy matic activity which cause cell death (Nikolaev et al ; 1986) .

A significant increase serum Alp , Acp and serum prostatic Acp activities in the serum treated rats . Our results are in agreement with Osada et al ;(1986,1988) and Zimmermann et al; (1985\& 1987). They also noticed increased serum transaminase $48 \mathrm{~h}$ and $72 \mathrm{~h}$ after TA administration. The increased alkaline and acid phosphatase in the prostatic tissue in the present study is in agreement with Osada et al ; (1988), Zimmerman et $a l ;(1987)$ and Fontana et al ; (1996).

They attribute this increase to the damage effect of thioacetamide on the tissue. The decrease in synthesis of glutathione in testis was noticed also by Cascale et al ; (1991) ; Kretzschmer et al ; (1991 )\& Fontana (1996) .
They attributed this decrease to hepatocellular damage induced by thioacetamide. Glutathione is a control to the antioxidant defense system of the cell. It can reduce ascorbic acid via a thiol transferase and acts as a substrate for GSH peroxides to reduce hydrogen peroxide (Meister, 1992 ). Furthermore, a reduction in GSH levels with increased age has been suggested as a mechanism for increased susceptibility to neoplasia (Richi ,1992 ).

In the present study oral administration of Panax ginseng root daily for a period of 10 days revealed a protective action against liver and testis induced by TA administration as indicated by the improvement of Alp , Acp prostatic Acp in serum and GSH , Alp ,Acp in tissue of testis . Lin et al ; (1995), stated that Panax ginseng root performed a protective role against the hazardous effect of TA. Red Panax ginseng extracts had a significant cancer chemopreventation at $50: 400 \mathrm{mg} / \mathrm{kg}$ in rat (Xiaoguang et al ; 1998 ). Huong et al; (1998), suggested that Vietnamese ginseng exerted a protective effect against free radical induced tissue injury and this effect was attributable to minor compo nents rather than the main saponin components From our present data it can be concluded that alterations of blood chemistry and testis material induced by TA toxicity could be improved in animals receiving Panax ginseng root this improvement is markedly achieved by pre-administration of Panax ginseng . Different types of damage could be noticed in testes \&epididymis of rats treated with TA . Ramaiah et al ; (1998), 
found that necrotic hepatocyts following administration of TA $(50 \mathrm{mg}$ $/ \mathrm{kg}$ ) were started at $12 \mathrm{~h}$ in rats and concordant with the plasma enzyme elevation. According to the present study histological lesions were detected after 24 ,48, 72h post- treatment . This was manifested by inhibition of spermat ogenesis in seminiferous tubules also the epididymal tubules showed a decrease in density of spermatozoa after $24 \mathrm{~h}$ posttreatment . After $48 \mathrm{~h} \& 72 \mathrm{~h}$ the effect of TA was increased. These results are in agreement with Hunag et al ;(1999), they noticed that TA treatment for 3 weeks reduced the liver specific MAT protein level to below $30 \%$ of control, where the type of MAT expression greatly influe nced the rate of growth and DNA synthesis (Cai et al ; (1998). Also Sanzet et al; (1995\&1998), found that the polyploidy hepatocyte population decrea sed Sharply in the periods between $24 \& 48 \mathrm{~h}$ in young animals and $48 \& 72 \mathrm{~h}$ in older ones after TA administration . The epididymal tubules in the present work were gradually surrounded by the fibers after TA administration. This fibroblastic proliferation observed is known to be a natural response for tissue to repair in healing processes following irreversible Damage . Fontana et al; (1996); Muller et al ; (1996) \&Torres et $a l$; (1997), noticed that ,the administ ration of TA in rats induced nodular cirrhosis of liver, characterized by fibrous septae parenchymal nodules , excessive deposition of connective tissue elements and proliferation of bile ducts . Pyknotic primary spermatocytes were detected in a considerable number of tubules at $48 \& 72 \mathrm{~h}$ after TA intoxication and some spermatogenic cells showed enlarged nuclei. These results are in agreement with Sanz et al ; (1995), they stated that hepatocytes isolated from TA treated rats showed a marked tendency to diploidy and a significant decline in antioxidant enzyme activity . Chanda \& Mehendale (1994), reported that, liver injury induced by TA peaked between $36 \& 48 \mathrm{~h}$ in rats. The low doses of TA stimulate hepatic DNA synthesis and mitosis in rats (Mangipudy,1995). These changes are associated with nuclear enlargement (Reddy et al ;1969). TA also affects the nucleic acid metabolism as evidence by increase in the nucleoli size and RNA transport inhibition from the nucleus to the cytoplasm (Clawson et al; 1980). Marked depletion in PAS +ve materials was observed in the present study gradually after $24,48 \& 72 \mathrm{~h}$ of TA administration. These results are in agreement with Ramaiah et al ; (1998), they noticed a significant decrease in the basal hepatic glycogen levels in rats after TA treatment .

Injection of rats with ginseng only, led to an increase in the activity of spermatogenesis in testes and in the density of spermatozoa in the epididymis . In agreement with the present findings in a similar study Bashandy et al; (1996), they found that ginseng increased motility of sperms and DNA content of spermatogenic cells and decreased the tail abnormalities in sperms. These effects may be due to the antioxidant nature of ginseng (Sohn et al ;1993). Additionally, Panax ginseng is free from any harmful side effects (Sanada et al; 1974; Shoji, 1974\&Aphale et al ;1998) .

In the present study, ginseng increased the PAS + ve materials in both testis \&epididymis . This is in agreement with Morsy et al ; (2002) they noticed an increase PAS +ve materials in the kidney of rats treated with ginseng for 8 weeks . The treatment of rats with ginseng 
partially conditioned the adverse effect of TA on testis . This plant exerted its prot ective activity against TA either directly by inhibiting lipid peroxidation and scavenging free radicals (Mei et al ; 1994), or in directly through enhancement of the activity of super oxide dismutase , an enzymatic free radicals scavenger in the cells (Xie et al ;1993) .

Also Panax ginseng was found to exert a stimulatory effect on DNA repair synthesis and has inhibitory effect on mutagenicity and cellular transformation (Nishino et al ;2001). Moreover it has promoting action on RNA synthesis in diabetic rats (Yokzawa et al ; 1996). Ginseng has a chemo preventive and therapeutic action and can enhance immune function prosperities (Shin et al ; 2000\&Xiaoguang et al ; 1998) .

Lee et al; (2002), stated that ginseng may reduce cell damage induced by toxic substances and acts to stabilize cell membranes by providing protection against toxic agents induced tissue injury

\section{Conclusion :}

From our present data it can be concluded that alteration of blood chemistry profile, histopathology \& hist ochemistry induced by TA toxicity could be improved in animals after receiving Panax ginseng root .

\section{References}

1. A phale .A.A. ; Cbhibba. A.D.; Kumbhakarna, N.R. ; Mateanuddin $M$.and. Dahat ,.S.H.. ( 1988) : Subacute toxic study of the combination of ginseng (panax ginseng) and ashwagandha (withania somnifera) in rats a safety assessment . Ind. J. Physiol. pharmacol .24(2):299:302
2. Bashandy , S.A. ;Nada , S.A.; Morsy , F.A . and Arbid , M.S. (1996) :The role of ginseng on gonad ochrasyoxicosis An rat .J. Union Arab. Biol. Cairo . 5(A) 22:250

3. Beutler , E.; Nuron , O. and Kelly , M.B. ( 1963): J. Lab. Clin. Med., 61: 882. Quoted from: Biochemical methods in red cell genetics ( 1969 ). Edd. J.J. Yunis Academic press. New york and London.

4. Brown,R.H. ( 1995 ) : Amylotrophic lateral sclerosis: recent insights from genetics and transgenic mice. Cell : 80,687- 692.

5. Cai, J.; Mao, Z.; Hwang, J.J. and Lu, S.C.( 1998) : Differential expression of methionine adenosyl transferase genes influences the rat of growth of human hepatocellular carcinoma cells. Cancer Res.

6. Cascaleo , M.; Martin - Sanz, P.; Craciunesca, D.G.; Mayo, I. And Cascales, C. ( 1991 ) : Alterations in hepatic peroxidation mechanism in thioacetamide - induced tumors in rats. Effect of a rabium ( III ) complex. Carcinogensis, 12:233-240

7. Chanda, S. ; and Mehendale, M. ( 994): Role of nutritional fatty acid and L. Carnitine in the final outcome of thioacetamide hepatotoxicity. F. A. S. E. B. J. ; 8 (13): 1061-8.

8. Clawson , G. A. ; Kophitz, M. ; Moody, D. E. and Smuckler, E. A . (1980) : Effects of thioacetamide treatment on nuclear envelop nucle oside triphophate activity and trans port of RNA from rat liver nclei. Cancer Res. 40:75-95

9. Drury, R. A. and wallington , E. A. (1980) : Carlton histological techniqu 4 Ed Oxford Uni . press, New york, Toronto .

10. Ferrando, A.vila, L.; Voces, J.; Cabral, A,; Alvare, A. and prieto ,J. (1999) : Effect of ginseng extract on various haematological parameters 
during aerobic exercise in the rat plasma. Medica, 65 : 288: 290

11. Fizhugh, D.H. and Nelson, A.A.( 1948 ) : Liver tumors in rats fed thiourea or thioacetamide. Science, 108:626.

12. Fontana, L.; Moreira, E. ; Torres, M.I.; Fernandez, M.I.; Rios, A.,deMedina, F. and Gil,A. ( 1996) :Serum amino acid changes in rats with thioacetamide - induced liver cirrhosis. Toxicology; 106 (1-3):197206

13. Food \&Drug Administration : copyright (1999): Medical Economics Company, Ine. Health privacy Policy

14. Gutterdage ， J.M.C. (1986) : Antioxidant properties of the proteins ceruloplasmin, albumin and transf errin. A S tudy of their activity in serum and synovial from patients rheumatoid arthritis. Biochem. Biophys. Acta, 869:119-127.

15. Huang, Z.Z.; Mato, J.M.; Kanel, G . and shelly, C. ( 1999) : Differential effect of thioacetamide on hepatic Methionine adenasyltrasferase expr ession in the rat. Hepatology 29 (5):1471-1478.

16. Hunter, A.L.; Halscher, H. A. and Neal, R. A. (1977) : Thioacetamideinduced hepatic necrosis. 1Involvement of the mixed function oxidase enzyme system . J. pharmacol. Exp .Ther ., 200:439

17. Huong, N.T.; Matsumoto, K.; Kasai, R.; Yamasake, K. and watanabe , H. ( 1998 ) : In vitro antioxidant activity of Vietnamese ginseng saponin and its components. Biol. Pharm,Bull.,21(9):978-9

18. Kim,V.; Park. K.and Rho, H. (1996) :Transcriptional activation of the cu-zn - superoxide dismutase gene through the AP 2 site by gin senoside $\mathrm{Rb} 2$ extracted from amedicinal plant panax ginseng .J. Biol. chem., 271 (40 ) : 24539:24543.
19. Kirtikar , K. and Basu , B. (1987) :In Indian Medicnal plantsed. Bye Blatter, J. Caius\& K. S. Mhaskar, 3:1773:1779, International Book Distribution, Dehradun.

20. Kitts, D. ; Wijawickreme , A. and Hu ,C - ( 2000): A antioxidants properities of a North American ginseng extract : Mol, cell. Biochem ., 203(1-2) : 1-10

21. Kochmar, J.F. and Moss, D. W. (1976): Fundanenais of clinical Chemistry, N. W. Tietz (ed. ), P:604 -W.B. Saunders and Company, Philadelphia, PA.

22. Lee, H.C.; Hwang, S.G.; Lee, Y.G.; Sohn, H.O.;Lee,D.W.; Hwang, S.Y. and Moon, J.Y. (2002): In vivo effects of panax ginseng extracts on the cytochrome P450 dependent monooxygenase system in the liver of $2,3,7,8$, tetrachlorodibenzo - p-dioxin- xposed guine pig. Life science, 71( 7) :757769

23. Lin , J.H; Wu. L.; S.; Tsai.,K.T.; Leu. S.P.; Jeang, Y.F.and Hsieh, M.T. ( 1995 ): Effects of ginseng on the blood chemistry profile of dexa methasone - treated male rats. Am. J. Clin. Med .23 (2) :167- 172.

24. Liu,. J; wang .S.; Lim. H. ;Yan . L. and Nan ,G. (1995) : Stimulatory effect of saponin from Panax ginseng on immne fnction of lymphocyts in the elderly. Mceh. Aging.

25. Maffel - Facino, R.; Carini, M.; Aldin, G. ; Berti, F. and Rossoni, G. (1999) Panax ginseng adminis tration prevents myocardial ischemia - repertusion amage induced by hyperbasic oxygen evidence for an anti oxidant. Plant Medica : 65( 7) : 614-619.

26. Mangipudy, R.S; Chanda, S. and Mehende , H.M. (1995) : Tissue repair as a response to thioacetamide hepatotoicity Environ. Health perspect. 103, 260-263. 
27. Mangipudy, R.S.; Roa, P.S. and Mehenden, H.M.(1996) : Effect of Calchicine antimitosis on thioace tamide hepatotoxica Environ. Health perspect. 104,744-749

28. Mangipudy, R.S. ; Chanda, S. and Mehenda, H. M. (1995): Hepatocellular regeneration: Key to thioacetamide autoprotection. Pharmacol - Toxicol. 77: 182-8.

29. Mei, B.; Wang, Y.F.; Wu, J.X. and chen ,W. Z.(1994): Protective effect of ginsenosides on oxygen Free radical induced damages of Cultured vascular endothelial cells in vitro Yao. Husch. Hsuch- pao.29(11) :801-808 .

30. Meister, A. (1992) : Commentary on the antioxidant effects of ascorbic acid and glutathione. Biochem. Pharmacol., 44:1905-1915.

31. Morsy, F.A.(2002): Protective effect of ginseng against toxic effect of ochratoxin ( OA ) in Kidney of male rats. Egypt. J. of Hosp. Med 7:151-167.

32. Moss, D.W. (1984) : In the methods of enzymatic analysis of acid phosphatase, Ed. H.U., Bergmeyer, Ver lag chemie, 3d edition, V.4, 92106.

33. Muller, D.; Enderle, G.J.; Low, O.; Dietze, E. and Krell, $H$. (1996) : Bile ductular proliferation and altered leukotriene elimination in thioacetamide - induced fibrosis of rat liver. J. Hepatol, 25 (4) :54753.

34. Nikolaev, V.; Kerimova, M.; Naydenova, E.; Dimov, S. and Savov, ( 1986 ) : The effect of thioacetamide on rat liver plasma membrane enzyme and its potentia tion by fasting. J.Toxicology, (38): 203-208.

35. Nishino , H.; Tokudd, H.;Mosuda, M.; Satomi, Y.;Okada,Y.and Okugama, T. ( 2001) : Cancer chemoperventation by ginseng in mouse liver and other organs. J. Korean. Med sci. , 16:566-579.

36. Osada, J.; Aylagas, H.;Miro obradors , M .J. and Palacios - Al aiz, E . (1988) : Lysophosphatidylclastine is implicated in thioacetamide induced liver necroses. Biochem . Biophys .Res . Commun ., $154: 803-808$.

37. Osada , J .; Aylagas , H .; sanchez - Vegazo I.; Gea , T .; Millan, and Palacios , E. ( 1986 ) : Effect of S Adenosyl - L methionine thioa cetamid - induced liver damage in rats . Toxicol . L ett, 32: 97-106.

38. Ramaiah , S.K.; Soni , M.G.; Bucci, I .J. and Mehendale, H.M. (1998): Diet restriction enhances compen satory liver tissue repair and survival following administration of lethal dose of thioacetamide, Toxicology \& app phar . 150, 12-21.

39. Reddy , J.; Chiga, M .; and Svaboda , D . (1969): Initiation of division cycle of rat hepatocytes following a single injection of thioacetamide .Lab . Invest . 20, 405411.

40. Rhee, Y.H.; Ahn,J.; Choe , J.; kang , K . W . and Joe ,C . (1990): Inhibition of mtugenesis and transformation by root extracit of panax ginseng in vitro . planta Med ., $57 ; 125-128$.

41. Richie , J. P. (1992) : The role of glutathione in aging and cancer. Exp . Gerontol ., 27: $615-626$

42. Sanada , S .; Kondo, N.; Shoji, J.; Tanaka, $O$.and shibata, S. (1974) :Studies on saponins of ginseng structures of ginsono side.Ro, Rbi , $\mathrm{Rb} 2, \mathrm{Rc}$ and Rd. Biol . pharm . Bul. , 22:421-428.

43. Sanz , N .; Diez - Fernandez , C . ; Alvarez , A . M .; Simon , L and Cascales , M . ( 1998 ) : Age related changes on parameters of experimentally - induced liver injury 
and regeneration. Toxicology and App . Pharm . 154 : 49-50.

44. Sanz, N.; Diez.; Fernandez,C.; Simon, L.;Alvarez., A.and ascales, M.(1995): Relationship between antioxidant systems, intracellular thiols and DNA ploidy in liver of rtas during experimental cirrliogenesis carcinogenesis, 16(7): 1585-1593.

45. Shin, H.R.; Kin, J.; Yum, T.K.; Morgan, G.and Vainio, H. (2000): the cancer preventive potential of panax ginseng are view of human and expirmental evidence cannier cause control.11 (6):565-567

46. Shoji,S.(1974): Some chemical studies on ginseng in proceeding of international ginseng symposium, PP.69-76-the central Res.Instit Office of Monopoly. Republic of Korea.

47. Snedecor,G.W.and Cochran, W.G. (1967): Statistical methods Iowa stata University press, Ames, Iowa.PP.5960.

48. Toh, H.(1994):Improved isolatad heart contractility and mitochondrial oxidation after chronic treatments. with panax ginseng in rat. Am.J. Clin- Med.22(3-4):275-284

49. -Torres,M.I.; Fernandez, M.I.; Gil, A. and Rios, A.(1997):Effect of dietary nucleotides on degree of fibrosis and steatosis induced by oral intake of thioacetamid. Dig. Dis. Sci, 42 (6):1322-8.

50. Troyer, H .(1980): Principles and techmigues of histocemistry. 1 st ed.p.104.Little Brown Company, Boston.

51. Um nova,N.V.;Michurina ,T.I; Smirnova,N.I.; Alksandrova,I. V. and Povoshenko,G. (1991):Study of anti-mutagenic properties of biog imser in mammalian cells in vitro and in vivo:Bull.Esp.Biol. Med. ,111(5): 507-509.

52. Xiaoguang , C.; Hongyan, L; Xiaohong, Z.; Zhaodi, F .; Yan,
L.;Lihua, T. and Rui, H. (1998): Cancer chemopreventive and ther apeutic activities of red ginseng. J. Ethopharmacol., 60(1): 71- 78.

53. Xie, Z. C. ; Qian, Z. K. ;Hium , Z.W. ( 1993 ) : Effect of ginseng on anti - peroxidate injury in myocar dium and erythrocytes In streptozocin induced diabetic rats. Chung Kuochung His. T.Chiech. Ho. Tsachi., 13(5): 289-290

54. Yang, Y. W; He, K. and Fu, Z. G. (1999) : Effect of ascorbic exercise and ginsenosides on lipid metabolism in diet induced hyperlipidemia mice. Chung. Kuo. Yao. Li. Hsueh. Pdo. ,20(6):563-565.

55. YoKozawa, T; Ya sui, T. and Qura, H. (1996) : Molecular biological analysis of the effects of ginsenoside - $\mathrm{Rb} 2$ on albumin mRNA in streptozotocin induced diabetic rats. J. Phar. Pharmacol ., 48:763-767.

56. Yun ., T. K. ; Lee , Y.s. ; Kwon, H. Y. and Choi, K. J. (1996) : Saponin contents and anticarcinogensis effects of ginseng depending on types and ages in mice - chung, Kuo yao. H,Li Hsuch, pao. 17(4): 293 - 298

57. Zimmermann, T.; Frank, H. and Dargel, R. ( 1985$)$ : Biochemical and substructural studies on hepatic serum lipopr otein metabolism after acute liver injury induced by thioacetamide in rats. Exp. Pathol., 28:225-233

58. Zimmermann, T.; Muller, A.; Machnik, G.; Franke, H.; Schubert, H. and Dargel, R. (1987) : Biochemical and morphological studies on production and regression of experimental liver cirrhosis induced by Thioacetamide in VJeWIST rats. Versuchstierka, 30:165.180. 


\title{
المعالجة المسبقة بالجنسيج تقلل الاضرار الحاده في خصيه الجرذان البيضاء المحدثة بالئه بالثيو أسيتاميد.
}

\author{
نهال علي مصطقي \& أميره تهامى

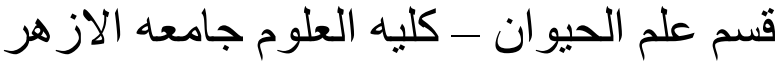

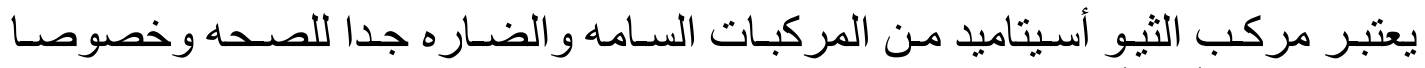

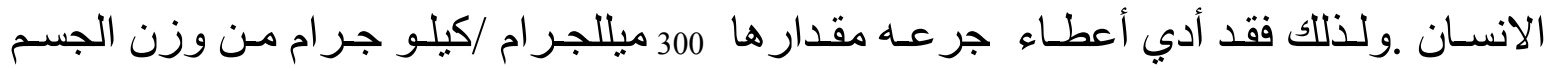

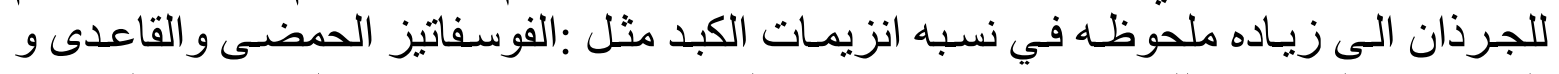

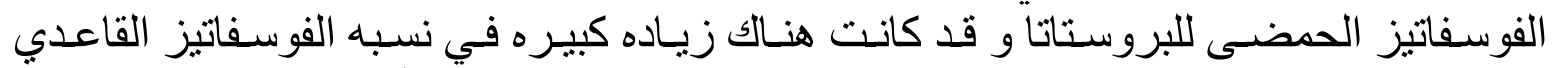

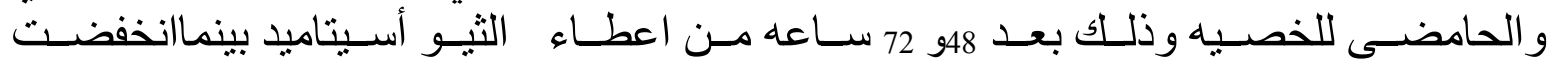

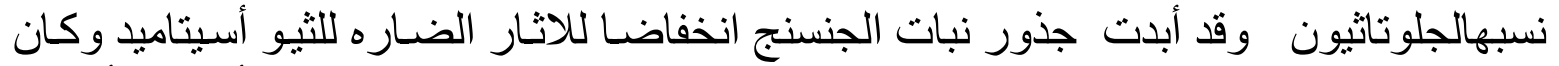

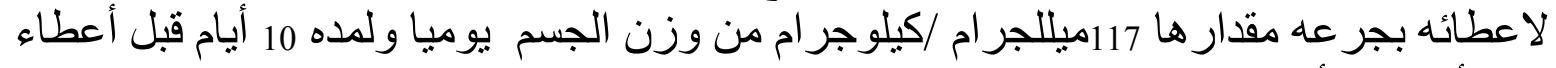

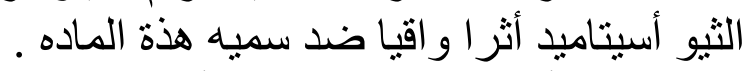

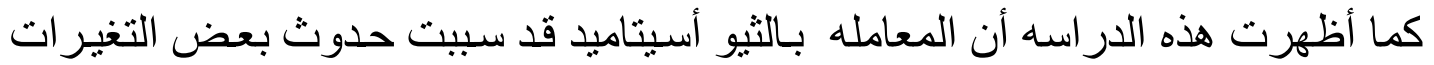

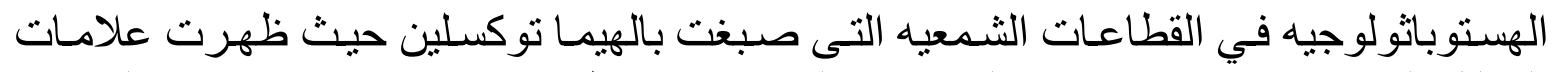

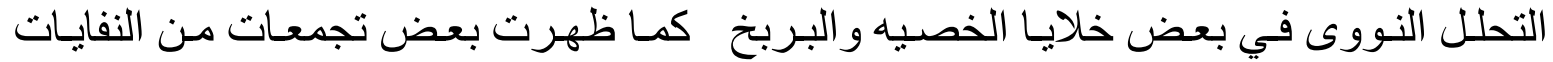

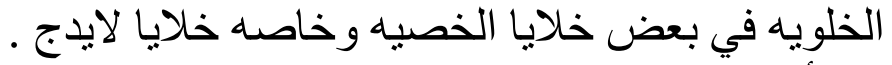

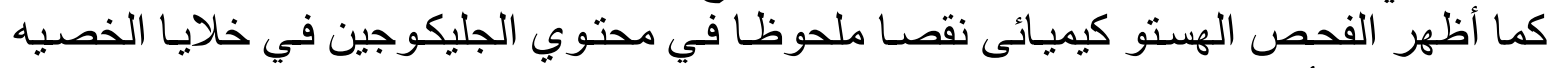

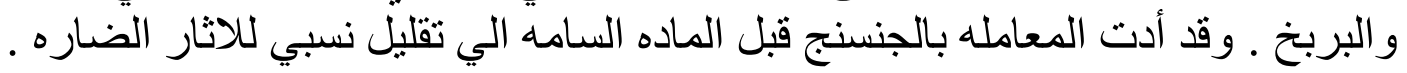

